\title{
Changing pattern of Typhoid fever complications in Indonesia
}

\author{
R.H.H. Nelwan
}

\begin{abstract}
Abstrak
Demam tifoid memiliki komplikasi yang sudah dikenal dengan baik seperti perdarahan usus dan perforasi, kegagalan sirkulasi perifer, dan juga komplikasi di hati yang dikenal dengan hepatitis tifoid, di jantung sebagai miokarditis atau di paru sebagai bronkhopneumonia tifoid. Beberapa komplikasi ringan telah dilaporkan termasuk pada tulang belakang, persendian atau ginjal. Komplikasi major lainnya termasuk manifestasi neuropsikiatrik yang kadang mengaburkan gambaran klasik demam tifoid, mulai dari sindroma ensefalopati, meningitis, defisiensi neurologik lainnya dan semua macam psikosis, Parkinsonisme sementara (Transient Parkinsonism) telah rutin ditemukan. Sejak mulainya dekade ini komplikasi lain selama demam tifoid telah terdeteksi, hal ini telah dilaporkan pada Kongres Demam Tifoid se Asia Pasifik. Ini merupakan gangguan pankreas yang pada waktu itu merupakan penemuan regional yang baru dan diduga terjadi secara tak sengaja dan diusulkan untuk diberi nama pankreatik tifoid. Waktu berlalu, frekuensi komplikasi ini dilaporkan meningkat, sebagai akibatnya sekarang selalu harus dipikirkan adanya komplikasi ini sewaktu mengobati pasien demam tifoid di Indonesia.
\end{abstract}

\begin{abstract}
Typhoid Fever has some well known complications like intestinal bleeding and perforation, peripheral circulatory failure and also complications in the liver known as typhoid hepatitis, in the heart presenting as myocarditis, or in the lungs known on typhoid bronchopneumonia. Some minor complications have been reported involving also the spine, joints or kidneys. Another major complication consisted of neuropsychiatric manifestation obscuring sometimes completely the classical picture of typhoid fever ranging from encephalopathic syndromes, meningitis, other neurological deficiences and all kinds of psychosis, transient Parkinsonism has also been observed regularly. At present, since the beginning of this decade, another disturbing complication during typhoid fever has been detected, duly reported already in the first Asian Pacific Congress of Typhoid Fever. It was a form of pancreatic disturbance at that time a novel regional finding that was thought to occur incidentally and was proposed to be termed typhoid pancreatis. As time went by this complication was reported in increasing frequencies to the effect that it has established itself now as a complication always to think of when treating typhoid fever patients in Indonesia.
\end{abstract}
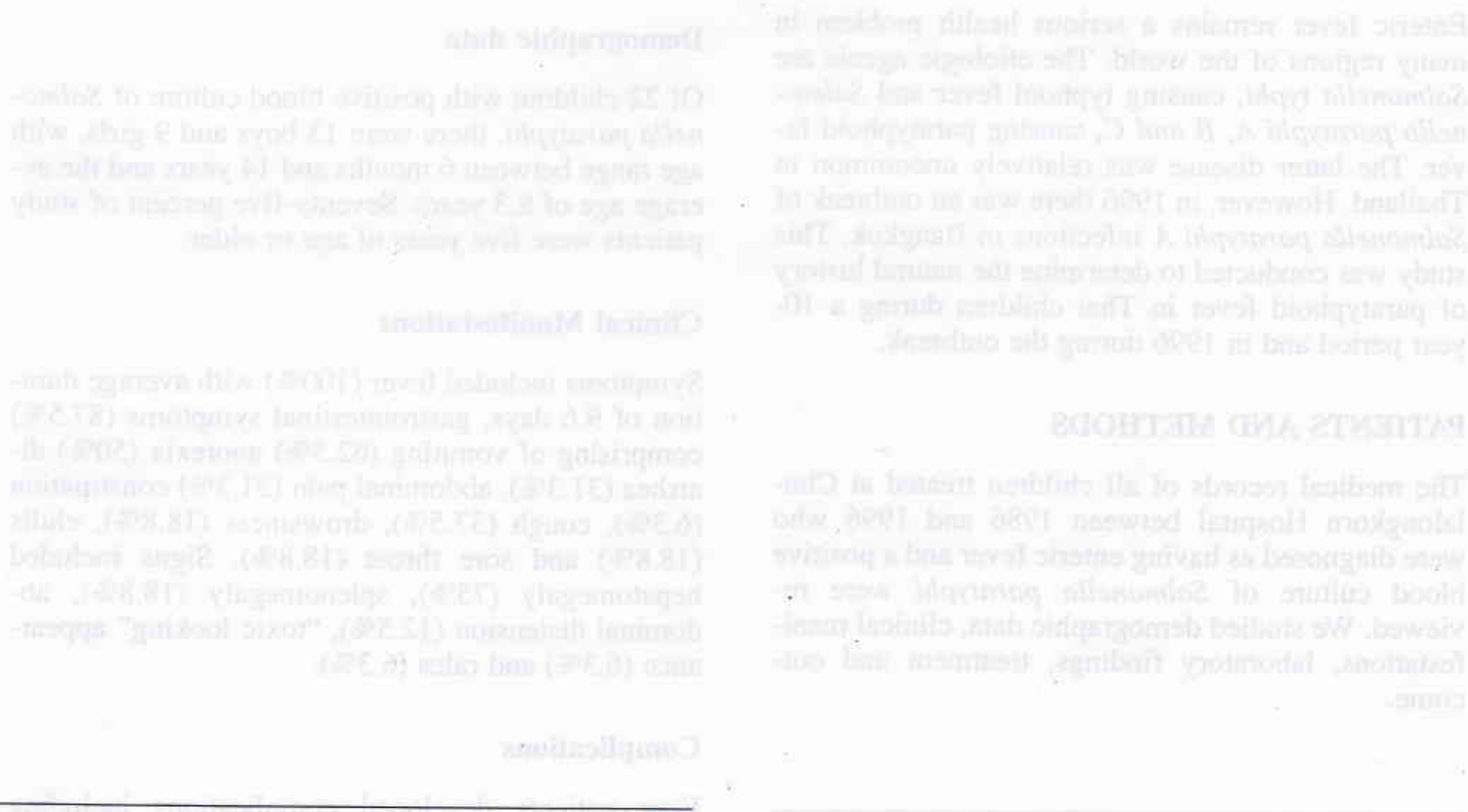

Infectious Diseases Working Group, Faculty of Medicine University of Indonesia, Jakarta, Indonesia 